\title{
Resistance of some Capsular Serotype D Strains of Pasteurella multocida to Rabbit Polymorphonuclear Neutrophil Phagocytosis
}

\author{
HOWARD G. RUSH \\ Unit for Laboratory Animal Medicine, Box 0614 Anımal Research Facility, University' of \\ Michigan Medical School, Ann Arbor, MI 48109 (US A)
}

(Accepted for publication 21 November 1988)

\begin{abstract}
Rush, H.G., 1989. Resistance of some capsular serotype D strains of Pasteurella multocida to rabbit polymorphonuclear neutrophil phagocytosis. Vet Microbiol , 20. $79-87$.

The mechanısm of resistance of Capsular Type D strains of Pasteurella multocida to kılling by rabbit polymorphonuclear neutrophils (PMN) was studied using an in vitro assay that differentrates intra-from extracellular bacteria. Two Capsular Type D strains (3761 and 3766), resistant to killıng by rabbit PMN, and one Type A strain (R1), susceptible to PMN destruction, were compared. After combining opsonized bacteria and PMN, the Capsular Type D Strains 3761 and 3766 remained extracellular whlle the Capsular Type A Strain R1 was internalized by PMN. Thus, both Type D strains were resistant to phagocytosis by rabbit PMN.
\end{abstract}

\section{INTRODUCTION}

Pasteurella multocida is the most common bacterial pathogen of rabbits (Flatt, 1974). Diseases of the upper and lower respiratory tracts are most common although septicemia, abscess formation and genital tract disease also occur (Flatt, 1974). Of the 4 capsular and 16 somatic serotypes of $P$. multocida described, Capsular Serotypes A and D and Somatic Serotypes 3 and 12 are most often recovered from rabbits (Lu et al., 1978; Brogden, 1980; Chengappa et al., 1982). Untypable strains also have been isolated (Lu et al., 1978).

The capsule of Serotype A strains of P. multocida has been shown to interfere with ingestion of Pasteurella organisms by phagocytic cells (Maheswaran and Thies, 1979; Ryu et al., 1984). Removal of the capsule, composed largely of hyaluronic acid, by treatment with hyaluronidase renders some Serotype A strains susceptible to phagocytosis (Maheswaran and Thies, 1979; Anderson et al., 1984). Recent evidence suggests that a component of the capsule other than hyaluronic acid is responsible for the capability of Pasteurella organisms 
to resist phagocytosis (Ryu et al., 1984). Consistent with this observation, we previously identified a Serotype A strain of $P$. multocida that remained resistant to ingestion even after treatment with hyaluronidase (Rush et al., 1981). In addition, an outer membrane protein from a Serotype A strain of $P$. multocida has been shown to inhibit mononuclear cell phagocytosis of Candida albicans in vitro (Truscott and Hirsh, 1988).

In addition to the previously reported resistance of Type A strains of $P$. multocida to ingestion by phagocytic cells, we have described 4 Serotype D strains of $P$. multocida that were resistant to phagocytosis and killing by rabbit polymorphonuclear neutrophils (PMN) (Anderson et al., 1984). Although we suspected that these strains were resistant to phagocytosis and not to intracellular bactericidal activity, the specific mechanism of resistance of these strains could not be determined because the experimental method used in these studies did not permit differentiation of resistance to phagocytosis from resistance to intracellular killing. The present study was undertaken to determine whether Serotype D strains were resistant to ingestion by rabbit PMN.

\section{MATERIALS AND METHODS}

\section{Bacteria}

Two Capsular Type D (3761 and 3766) and one Capsular Type A (R1) strains of $P$. multocida isolated from rabbits were used. The serotypes of the strains were: R1 (3,12:A), 3761 (3,12:D) and 3766 (12,7:D) (Rush et al., 1981; Anderson et al., 1984). Prior to conducting the experiments, the optical densities of various dilutions of bacteria in log phase growth were determined and the numbers of viable bacteria in each dilution determined by plate count technique. From this information, standard curves were developed to correlate the numbers of viable bacteria in log phase growth with optical density (Koch, 1981). For use in experiments, bacteria were grown in brain-heart infusion (BHI) broth (Gibco Laboratories, Grand Island, NY), collected by centrifugation and washed with Hanks Balanced Salt Solution (Gibco Laboratories, Grand Island, NY) containing 10\% fetal calf serum (Gibco Laboratories, Grand Island, NY) (HBSS-FCS). The bacterial suspension was adjusted spectrophotometrically to a concentration of $1 \times 10^{8}$ bacteria $\mathrm{ml}^{-1}$.

\section{Antisera}

Antisera were prepared against each of the 3 strains (R, 3761, 3766) of $P$. multocida to be tested. Bacteria were grown on $5 \%$ sheep blood agar plates (BAP) (Gibco Laboratories, Grand Island, NY), harvested with 3\% formalin in saline and washed 3 times with saline. The final pellet was lyophilized. To prepare strain-specific antisera, a Pasteurella-free (PF) New Zealand White 
rabbit (Hazelton Dutchland, Inc., Denver, PA) was injected subcutaneously with one of the 3 test strains of $P$. multocida ( $1 \mathrm{mg}$ dry wt. $\mathrm{kg}^{-1}$ body wt.) in complete Freund's adjuvant. The animal was boostered 1 week later and antiserum collected 5 days after the second injection. Antisera were stored in 1-ml aliquots at $-70^{\circ} \mathrm{C}$. Antisera were designated anti-R1, anti-3761 and anti-3766.

\section{Polymorphonuclear neutrophils}

PMN were harvested from the peritoneal cavity of a PF rabbit following infusion of $0.1 \%$ glycogen in saline as described previously (Hofing et al., 1979). After $10-12 \mathrm{~h}$, the peritoneal cavity was washed with heparinized saline and the PMN collected through a $10 \mathrm{~F}$ catheter inserted aseptically through the abdominal wall. The cells were washed 3 times with HBSS-FCS, counted on a hemacytometer, and adjusted to a final concentration of $2.5 \times 10^{7} \mathrm{PMN} \mathrm{ml}^{-1}$. The cell population was approximately $90 \% \mathrm{PMN}$ and $90-95 \%$ viable by trypan blue exclusion. Where indicated, PMN were treated with $320 \mu \mathrm{g} 8-(\mathrm{N} . \mathrm{N}-$ diethylamine)-octyl-3,4,5-trimethoxybenzoate hydrochloride (TMB-8) (Sigma, St. Louis, MO) in $0.070 \mathrm{ml}$ Tris buffer (a $700 \mu \mathrm{M}$ solution prepared by dissolving $10 \mathrm{mg}$ of TMB-8 in $1.157 \mathrm{ml}$ of Tris buffer, $\mathrm{pH} \mathrm{7.2)} \mathrm{prior} \mathrm{to}$ mixing with bacteria (Rush and Moore, 1988).

\section{$P M N$ bactericidal assay}

The survival of Pasteurella organisms in the presence of rabbit PMN was evaluated using a modification of the methods of van Furth et al. (1978) by determining the total number of viable bacteria at 0 and 20 min after mixing of opsonized bacteria with PMN. The target strain of $P$. multocida was opsonized with homologous strain-specific antiserum (i.e. anti-R1, anti-3761 or anti$3766)$. Opsonized bacteria $\left(2 \times 10^{7}\right)$ and PMN $\left(1 \times 10^{7}\right)$ were combined (total volume $=1 \mathrm{ml}$ ). Controls consisted of: (1) bacteria without PMN or serum; (2) bacteria and serum without PMN; (3) nonopsonized bacteria and PMN. Samples $(0.01 \mathrm{ml})$ were taken immediately for determination of the total number of bacteria in the inoculum $\left(K_{0}\right)$. Samples were placed in $1 \mathrm{ml}$ sterile distilled water containing $0.01 \%$ gelatin, then vortexed $(1 \mathrm{~min})$ to facilitate osmotic lysis of neutrophils. The suspension was serially diluted in saline containing $10 \%$ fetal calf serum (saline-ECS). Aliquots $(0.1 \mathrm{ml})$, representing 3 different dilutions of the original sample taken, were transferred from the dilution tubes using micropipettors (Brinkmann Instruments Co., Westbury, NY), onto dextrose starch agar (Gibco Laboratories, Grand Island, NY) plates in duplicate and, using a standard spread plate technique (Koch, 1981), were dispersed uniformly over the surfaces of the plates, using sterile glass rods.

After removal of the samples at zero time $\left(K_{0}\right)$, the suspensions were incu- 
bated for $20 \mathrm{~min}$ at $37^{\circ} \mathrm{C}$ with rotation and samples were removed again for determination of the total number of viable bacteria remaining $\left(K_{20}\right)$. Samples were processed as described above. Plates were incubated overnight at $37^{\circ} \mathrm{C}$. When discrete colonies of approximately $1 \mathrm{~mm}$ diameter had grown, the number of colony forming units (CFU) on each plate was determined, using a semiautomatic colony counter (Fisher Scientific Inc., Springfield, NJ).

The percentage survival of bacteria after $20 \mathrm{~min}$ incubation in the presence of rabbit neutrophils was calculated using the formula: $K_{20} / K_{0} \times 100$, where $K_{0}$ was the total number of viable bacteria in the inoculum and $K_{20}$ was the number of surviving CFU after 20 min incubation with rabbit PMN. Using this mode of expression, if bacteria susceptible to killing by neutrophils, bacterial numbers decrease and percentage survival approaches $0 \%$, but if bacteria are resistant to PMN killing bacterial numbers remain constant or increase and percentage survival equals or exceeds $100 \%$. Each experiment was repeated 3 times $(n=3)$.

\section{PMN phagocytosis assay}

In order to ascertain whether $P$. multocida organisms were ingested after combining opsonized bacteria and neutrophils, the location, i.e. intra- or extracellular, of PMN-associated Pasteurella organisms was determined using the method of Rush and Moore (1988). The assay was performed under phagocytosing conditions, in which PMN can ingest but cannot kill ingested bacteria, and under control (non-phagocytosing) conditions, in which PMN ingestion and bactericidal activity are inhibited throughout the assay.

Under normal, phagocytosing conditions, the procedures were as follows. PMN were pretreated with TMB-8 ( $320 \mu \mathrm{g}$ in $0.070 \mathrm{ml}$ Tris buffer, $\mathrm{pH} 7.2$ ), an inhibitor of neutrophil degranulation and killing of bacteria (Smith and Iden, 1979; Hoffstein et al., 1982; Rush and Moore, 1988). Treated PMN and opsonized $P$. multocida were combined (final volume $=1 \mathrm{ml}$ ) and incubated with rotation to promote neutrophil ingestion of bacteria. After the phagocytic period, the suspensions were placed on ice to halt phagocytosis and centrifuged to remove non-cell-associated bacteria. The pellets were resuspended, TMB-8 was added again as well as $100 \mathrm{U}$ heparin (Elkins-Sinn Inc., Cherry Hill, NJ), an inhibitor of PMN ingestion (Victor et al., 1981) (final volume $=1 \mathrm{ml}$ ). Samples were removed and the initial number of viable PMN-associated bacteria $\left(S_{0}\right)$ was determined by standard dilution and plate count technique. Streptomycin $(100 \mu \mathrm{g})$ (Sigma, St. Louis, MO), an antibiotic that is poorly taken up by rabbit neutrophils (Yourtee and Root, 1982), was added to kill extracellular bacteria. The minimum inhibitory concentration of streptomycin for the 3 test strains ranged from 16 to $100 \mu \mathrm{g} \mathrm{ml}^{-1}$ (data not shown). The suspensions were incubated $\left(37^{\circ} \mathrm{C}, 20 \mathrm{~min}\right)$, samples were removed again and bacterial numbers were determined $\left(S_{20}\right)$. Percentage killing of bacteria by 
streptomycin was calculated according to the formula: $\left(S_{0}-S_{20}\right) / S_{0} \times 100$, where $S_{0}$ is the number of neutrophil-associated CFU prior the addition of streptomycin and $S_{20}$ is the number of surviving CFU after 20 min incubation with streptomycin. Under non-phagocytosing control conditions, PMN phagocytosis and killing of bacteria were completely inhibited by pretreatment of PMN with both TMB-8 and heparin prior to mixing with bacteria.

In the PMN phagocytosis assay, if ingestion has occurred, PMN-associated bacteria are intracellular and protected from the bactericidal action of streptomycin. However, if phagocytosis has not occurred (as in the non-phagocytosing controls ), PMN-associated bacteria are extracellular, and killing of bacteria by streptomycin can be detected.

\section{RESULTS}

\section{Susceptiblity to PMN bactericidal activity}

The results, shown in Table 1, demonstrate that the Capsular Type A Strain R1 was killed by rabbit PMN while the Capsular Type D Strains 3761 and 3766 were not. Indeed, growth of strain 3766 was recorded. Only $12 \%$ of Strain $\mathrm{R} 1$ bacteria survived after incubation with rabbit $\mathrm{PMN}$ while the numbers of Strains 3761 and 3766 bacteria increased to 107 and $160 \%$ of those in the original inocula, respectively.

\section{Susceptibllity to PMN phagocytosis (localization of cell-assoclated bacteria)}

The results are shown in Table 2. Under phagocytosing conditions in which PMN were pretreated with TMB-8 only, and heparin and streptomycin were added post-phagocytosis, only $8 \%$ of $\mathrm{PMN}$-associated strain R1 bacteria were killed by streptomycin. In contrast, under non-phagocytosing control conditions in which PMN phagocytosis and killing of bacteria were completely inhibited by treatment of neutrophils with both heparin and TMB-8 prior to

TABLE 1

Susceptiblity of 3 strains of $P$ multoc $d a$ to killing by rabbit PMN

\begin{tabular}{llll}
\hline Strain & $\begin{array}{l}\text { Capsule } \\
\text { type }\end{array}$ & $n^{\mathrm{a}}$ & $\begin{array}{l}\text { Percentage } \\
\text { survival }^{\mathrm{b}}\end{array}$ \\
\hline $\mathrm{R} 1$ & $\mathrm{~A}$ & 3 & $12 \pm 12$ \\
3761 & $\mathrm{D}$ & 3 & $107 \pm 5$ \\
3766 & $\mathrm{D}$ & 3 & $160 \pm 81$ \\
\hline
\end{tabular}

${ }^{a} n=3$ experiments conducted on different days.

${ }^{b}$ Values represent percentage survival \pm SD of $P$ multoctda organisms in the presence of rabbit PMN. Values greater than $100 \%$ indicate bacterial growth 
TABLE 2

Suscept 1 bility of $P$ multocida strains to killing by streptomycin

\begin{tabular}{lcccc}
\hline \multirow{2}{*}{$\begin{array}{l}n^{\mathrm{a}} \\
\end{array}$} & & \multicolumn{2}{l}{ Percentage killing of strain $^{\mathrm{c}}$} \\
\cline { 2 - 5 } & & $\mathrm{R} 1$ & 3761 & 3766 \\
\hline Phagocytosing $^{\mathrm{d}}$ & 9 & $8 \pm 8^{\mathrm{e}}$ & $98 \pm 2$ & $93 \pm 4$ \\
Non-phagocytosing $^{\mathrm{d}}$ & 9 & $96 \pm 2^{\mathrm{e}}$ & $98 \pm 1$ & $93 \pm 3$ \\
\hline
\end{tabular}

${ }^{a} n=3$ experiments performed in triplicate $(3 \times 3=9)$. Experiments were conducted on 3 different days

"Values represent the mean percentage killing of bacteria \pm S.D. by $100 \mu \mathrm{ml}^{-1}$ of streptomycin.

'Capsule types given in Table 1.

${ }^{\mathrm{d}}$ Under phagocytosing conditions, PMN can ıngest but cannot kill ingested bacterıa whle under non-phagocytosing (control) conditions PMN ingestion and bactericidal activity are inhubited throughout the assay.

"Significantly different at $P<0.01$ using paired sample $t$-test.

mixing with bacteria, $96 \%$ of cell-associated Strain R1 bacteria were killed by streptomycin $(P<0.01)$. These results indicate that, under normal phagocytosing conditions, most Strain R1 bacteria were intracellular and, therefore, unaffected by the presence of the antibiotic.

When the cellular location of the Type D strains was examined, we found that, under phagocytosing conditions, 98\% of PMN-associated Strain 3761 bacteria and $93 \%$ of cell-associated Strain 3766 bacteria were killed by streptomycin, suggesting an extracellular location for these organisms. In the corresponding non-phagocytosing controls, neither Type D strain was ingested by heparin/TMB-8-treated neutrophils and consequently cell-associated Strain 3761 and Strain 3766 bacteria were killed by streptomycin $(3761,98 \% 3766$, $93 \%$ ). The results indicate that under conditions in which phagocytosis could occur, both Type D strains of $P$. multocida remained extracellular and were, therefore, killed by streptomycin. Thus, the mechanism of resistance to destruction by PMN of some Type D strains of $P$ multocida is resistance to phagocytosis.

\section{DISCUSSION}

In previous reports, only Capsular Type A strains of $P$. multocıda have been examined and been shown to be resistant to phagocytosis by PMN (Maheswaran and Thies, 1979; Rush et al., 1981). Maheswaran and Thies (1979) described a Capsular Type A bovine isolate of $P$. multocida, NA77, that was resistant to ingestion by bovine neutrophils. Treatment of this strain with hyaluronidase rendered the organisms susceptible to ingestion. Similarly, we described earlier a strain of $P$. multocida from rabbits that was not ingested and 
killed by rabbit PMN but became susceptible to PMN destruction when treated with hyaluronidase (Anderson et al., 1984). Recently, Ryu et al. (1984) isolated a bacterial fraction from each of 2 type A strains of $P$. multocida that inhibited ingestion of Staphylococcus aureus by bovine PMN. Treatment of this fraction with hyaluronidase had no effect on the inhibitory activity, suggestive that the anti-phagocytic factor was not hyaluronic acid. In support of this observation, we previously described a Capsular Type A strain whose resistance to phagocytosis was unaffected by hyaluronidase treatment (Rush et al., 1981). An outer membrane protein from a Capsular Type A strain of $P$. multocida also has been shown to have anti-phagocytic activity (Truscott and Hirsh, 1988).

Only recently has the resistance to destruction by phagocytic cells of another capsular type of P. multocida been described (Anderson et al., 1984). Four Capsular Type D strains of $P$. multocida isolated from rabbits were not killed by rabbit PMN while a Capsular Type A strain, incubated under identical conditions, was killed. The results presented in Table 1 are consistent with those earlier findings. The objective of the study reported here was to document the mechanism by which some Type D strains of $P$. multocida resisted killing by rabbit neutrophils. Specifically, we addressed the question of whether 2 Type D strains of $P$. multocida that were not killed by rabbit PMN were either (1) not ingested by rabbit neutrophils and hence not killed, or (2) ingested by rabbit PMN but resisted intracellular bactericidal activity. Our approach was to determine the location, i.e. intra- or extracellular, of PMN-associated bacteria after an appropriate period in which phagocytosis could occur. The extracellular location of the Type D PMN-associated Pasteurella organisms, as shown in the present study, indicates that the survival of Capsular Type D strains of $P$. multocida in the presence of PMN is due to bacterial resistance to phagocytosis.

Encapsulation of bacteria often has been associated with bacterial resistance to ingestion by phagocytic cells (Howard and Glynn, 1971; Peterson et al., 1978; Weinstein and Young, 1978; Denson and Mandell, 1980; Stevens et al., 1980 ). The specific mechanisms by which the bacterial capsule prevents phagocytosis of bacteria would include interference with the deposition of opsonins on the bacterial surface and inhibition of bacterial attachment to the neutrophil membrane (Denson and Mandell, 1980). Since the resistance of Pasteurella organisms to ingestion by PMN is similar to that seen with other encapsulated bacteria it may be hypothesized that the capsule commonly found on Pasteurella organisms (Carter, 1967; Collins, 1977) is, at least in part, responsible for the expression of this virulence trait. Previous studies in which Pasteurella organisms were decapsulated with hyaluronidase are strongly suggestive that this is indeed the case (Anderson et al., 1984; Maheswaran and Thies, 1979). However, isolation and identification of the specific capsular anti-phagocytic factor from P. multocida would be required to validate this hypothesis. 
Further studies also will be required to determine the role of the Pasteurella anti-phagocytic outer membrane protein in the virulence of $P$. multocida.

\section{ACKNOWLEDGEMENTS}

This work was supported by Public Health Service grant RR01619 from the Division of Research Resources, National Institutes of Health.

I greatly appreciate and acknowledge the excellent technical assistance of Karen E. Moore.

\section{REFERENCES}

Anderson, L.C., Rush, H G. and Glorioso, J.C , 1984. Strain differences in the susceptibility and resistance of Pasteurella multocida to phagocytosis and killıng by rabbit polymorphonuclear neutrophils. Am. J. Vet Res., 45. 1193-1198.

Brogden, K.A., 1980. Physiological and serological characteristics of 48 Pasteurella multocida cultures from rabbits. J. Clin. Microbiol., 11· 646-649.

Carger, G.R., 1967 Pasteurellosis: Pasteurella multoctda and Pasteurella hemolytıca. Adv. Vet Sci , 11: 321-379.

Chengappa, M.M., Myers, R.C. and Carter, G.R., 1982 Capsular and somatic types of Pasteurella multoctda from rabbits. Can J. Comp. Med., 46: 437-439.

Collıns, F.M., 1977. Mechanisms of acquired resistance to Pasteurella multoctda infection: A review Cornell Vet , 67: 103-138

Denson, P. and Mandell, G.L., 1980. Phagocyte strategy vs. microbial tactıcs. Rev. Infect. Dis , 2: 817-838

Flatt, R.E., 1974. Bacterial diseases. In: S.H. Weısbroth, R.E Flatt and A.L Kraus (Edıtors), The Biology of the Laboratory Rabbit. Academic Press, New York, pp. 194-231.

Hoffstein, S.T , Korchak, H M., Smolen, J.E. et al , 1982 Early consequence of neutrophil act1vation and their association with degranulation. In: Phagocytosis - Past and Future New York, Academic Press, pp. 47-65.

Hofing, G.L, Rush, H.G, Petkus, A.R. and Glorioso, J.C., 1979 In vitro kılling of Pasteurella multocıda: The effect of rabbit granulocyte and specific antibody source Am J. Vet. Res, 40: 679-683.

Howard, C.J. and Glynn, A.A , 1971. The virulence for mice of strans of Escherichia coll related to the effects of $\mathrm{K}$ antigens on their resistance to phagocytosis and killing by complement Immunology, 20: 767-777.

Koch, A.L., 1981. Growth measurement. In: P. Gerhardt, R.G.E. Murray, R N. Costilow et al (Editors), Manual of Methods for General Bacterıology. Amerıcan Society for Microbıology, Washington, DC, pp. 179-207.

Lu, Y.S , Ringler, D.H. and Park, J.S., 1978 Characterization of Pasteurella multocida isolates from the nares of healthy rabbits and rabbits with pneumonia. Lab Anim. Sci., 28 691-697

Maheswaran, S.K. and Thies, E.S , 1979. Influence of encapsulation on phagocytosis of Pasteurella multocida by bovine neutrophils. Infect. Immun., 26. 76-81

Peterson, P.K., Wilkinson, B.J., Kım, Y., Schmeling, D. and Quie, P.G., 1978. Influence of encapsulation on staphylococcal opsonization and phagocytosis by human polymorphonuclear leukocytes. Infect. Immun., 19. 943-949.

Rush, H.G and Moore, K.E., 1988. A method to detect rabbit neutrophil phagocytosis of Pasteurella multocıda. Am J Vet. Res, 49-1415-1418. 
Rush, H.G., Glorıoso, J.C., DaRif, C.A. and Olson, L.C , 1981. Resistance of Pasteurella multoctda to rabbit neutrophil phagocytosis and killıng. Am. J. Vet Res , 42: 1760-1768.

Ryu, H K., Kaeberle, M.L, Roth, J A. and Griffith, R W., 1984. Effect of type A Pasteurella multocıda fractions on bovine polymorphonuclear leukocyte functions. Infect. Immun., $4366-$ 71

Smith, R.J. and Iden, S.S., 1979. Phorbol myristate acetate-induced release of granule enzymes from human neutrophils: Inhibition by the calcıum antagonist, 8-(N,N-diethylamino)-octyl 3,4,5-trimethoxybenzoate hydrochloride. Biochem. Biophys. Res. Commun., 91, 263-271.

Stevens, P., Chu, C L. and Young, L.S , 1980. K-1 antigen content and the presence of an additional sialıc acid-containing antigen among bacteremic K-1 Escherichıa coll. Correlation with susceptibility to opsonophagocytosis. Infect. Immun., 29: 1055-1061.

Truscott, W.M. and Hursh, D.C., 1988 Demonstration of an outer membrane protein with ant1phagocytıc activity from Pasteurella multocıda of avian origin. Infect Immun.. 56 1538-1544

Van Furth, R.. van Zwet, T.L and Leijh, P.C.. 1978. In vitro determination of phagocytosis and intracellular killing by polymorphonuclear and mononuclear phagocytes. In· D M Weir and M.D. Edin (Editors), Handbook of Experımental Immunology, Vol 2. Blackwell Scientific, Oxford, pp. 32.1-32.19.

Victor, M , Weıss, J. and Elsbach, P., 1981. Heparin inhıbits phagocytosıs by polymorphonuclear leukocytes. Infect. Immun., 32: 295-299

Wemstein, R. and Young, L.S , 1978. Phagocytic resistance of Escherichla coll K-1 isolates and relationship to virulence. J Clin. Microbiol., 8: 748-755.

Yourtee, E.L and Root, R.K., 1982. Antibiotic-neutrophl interactions in microbial kılling. In: J.I. Gallın and A.S Fauci (Edıtors), Advances in Host Defense Mechanısms Raven Press. New York, pp 187-209. 